\title{
Effect of profession on managing work life balance of working women in India
}

\author{
Minal Bhartiya ${ }^{1, *}$, Sachin Mittal', Sangeeta Jain ${ }^{3}$ \\ ${ }^{1}$ Research Scholor, ${ }^{3}$ Professor, Institute of Management Studies, Devi Ahilya University, Indore, Madhya Pradesh, ${ }^{2}$ Faculty, \\ Jaipuria Institute of Management, Indore, Madhya Praddesh, India
}

*Corresponding Author:

Email: amijain108@gmail.com

\begin{abstract}
Indian society mainly has deep rooted close connection of family system, where Indian women has the role to play as nurturers and caretakers of whole family. India, in her transition phase, post independence faced lot of challenges at all levels of the society. With modernization and globalization, India people were worried with future and culture shocks. It was big paradigm shift for Indian closed mindsets. Out of the need of the hour, situations and circumstances, and many reasons led Indian women to go out for work for living. Soon, the concept of egalitarian society and women empowerment at every stage from Indian girls to Indian women reach the horizon of their career. But it was found that even after reaching to top, Indian women have to work wholly on her family roles. Stages comes into life of women - from marriage to children to care takers and other extremes situations, where she has to compromise in career. Hence it is the need to examine the phenomenon of the work-life balance of Indian women professionals in greater depth. The key research question: To identify the core reasons and challenges Indian women face for effective work life balance? To determine the work life balance and its related factors influence the Indian women professionals? To develop the strategies to apply for satisdfying work-family balance. First the emerging themes must be understood in the light of the literature on work-family balance. Then conclusions to be drawn on how women professionals in India manage their lives.
\end{abstract}

Keywords: Indian Women, Profession, Business Class, Service Class, Work Life Balance, Working Women.

\section{Introduction}

Significant and positive transformation of the society of women rises in every profession. Indian women have been contributing in various areas of economy. Professions starting from Academicians, Nursing, Adminstration, Financial Institutions, Educational Institutions, Medical Practioners, Consultants, Engineering Sector, Defence Sector, Entrepreneur Segment, Politics, High Profile Corporate Jobs, etc. There was a promising growth of women in leading positions across the globe. Yet, very few women reach to senior positions in their career ladder. While they were mostly concentrated in lower and middle levels, statistics stated that globally, women comprised only $10 \%$ of the senior managers in the Fortune 500 companies; It was found that different professions has an impact on work life balance of Indian working women.

A broad literature review on barriers to women's career progress suggests that one of the key reasons stopping women's rise to top positions is the work-life conflict. Women professionals experience it because of their strong commitment to family responsibilities. It significantly affected the quality of family life and career success of women.

\section{The Review of Literacture}

Frone et. al. (1992) based on findings, suggested that work boundaries to family demands were less than family boundaries to work demands. Women were more affected than men due to household responsibilties. However multiple roles give multiple satisfactions for working women, but a blend of career and family roles would also lead to stress, conflict and overload. Brown (1996) suggested that personality and situational factors affects job involvement. The public and private sector workforces were found to have systematic differences.

Hyman (2003) found the inter-conflict of work and family life of work fields: IT and call centers. Adverse effect were both tangible as unpaid overtime and intangible as stress and exhaustion. Jaafari (2003) studied on complex society and its relationship to Project Management. Research is required to redefine a fresh understanding of Project Management and the way to respond to the complex society challenges. Lockwood (2003) shared that the work or life programs had the prospective to significantly improve: the reduced absenteeism, employee morale and retain organizational knowledge, especially in difficult economic times. In current global souk, as organizations' aim to reduce costs, it is now the responsibility of the human resource professional to realize the critical issues of work life balance and campaigner of work life programs. Be it workforce whose friends and or family members were called to serve their country, single mothers trying to raise their children and make a living. Generation $\mathrm{X}$ and $\mathrm{Y}$ workforce who value personal time, couples struggling to manage dual-career marriages, or organizations losing critical knowledge when staff leave for other opportunities, work life programs offer a win-win situation for business owners and working persons. 
Perrons (2003) found the relationship between work-family balance and quality of life. 55 in-depth interviews with managers, working persons in MSME and new media owners were taken. Indicated the gender-differentiated patterns of ownership and earnings; long hours, flexible working patterns, home working. Thought on whether these working patterns were compatible with a work-life balance. Results showed that though new media builds new opportunities to join caring responsibilities with interesting paid work, a marked gender imbalance remains.

Haworth (2004) identified economic development, changes in social environments and globalization had put the relationships between work, social structure, leisure and quality of life in the limelight. Profound transformations in the nature and organization of work were coming up with potentially far-reaching social and economic consequences. Organizations demand greater flexibility from their workforces and started introducing new practices and technologies in response to global cut-throat pressures. At the same time, working persons were experiencing job insecurity, long working hours, greater than ever work - loads along with the challenge of balancing work and domestic responsibilities.

Butler et al., (2005) surveyed for 14 days 91 parents working in non-professional occupations about their job characteristics and work family conflict. Results depicted that there was significant daily variation in Work to Family Facilitation (WFF) and Work to Family Conflict (WFC) which was predictable from daily job characteristics. Every day skill levels used at work were not related to per day WFC. Work schedule flexibility has been found to be negatively associated with work life balance or work family conflict. Higher the flexibility lower is the work family conflict. This implies that the higher the work schedule flexibility, higher is the work life balance.

Baral (2010) studied 48,537 professionals and revealed that working women and men in India experienced more work family enrichment than the work family conflict. Suggested that organizations were required to incorporate work life balance policies and encourage a culture that support utilizing them to ensure employee commitment and productivity.

Muthumani (2013) discovered that developing and creating constructive work environment would build quality of work life of IT professionals. The research carried on 120 respondents of Coimbatore IT Companies. Research depicted a positive correlation among conductive work environment and quality of work life like, Job rotation, relationship between colleagues, career growth and development, smooth relation with supervisor, job enrichment, autonomous work groups, balance with work and non-work life, flexi time and management of employee stress. K.Thriveni (2013) explored the understanding of the effect of family responsibilities on the professional decisions of working women. Shravanthi (2013) found that work and life programs had the potential to significantly enhance employee morale, retain organizational knowledge and reduce absenteeism, specially in difficult economic times.

\section{Women Entrepreneurs in India}

Dileepkumar (2006) discussed on certain issues faced by entrepreneurial women, like male dominance, a lack of education, required motherly duties, limited mobility, a shortage of finances and lack of achievement motivation. Mathew (2011) suggested that women entrepreneurs experienced high degree of role overload and associated Work Life Balance issues. Two more important findings were also explained by the study i.e. health issues among female entrepreneurs and work to family conflict as an outcome from the inability to manage time properly.

J. Sudha (2014) shared that to achieve proper work life balance, every working female should fix her objectives and should plan their working properly between career and family. Study also suggested some of the startegies like skill based work, part time work, work from home, could be used at work and home place for accomplishing a satisfying and fulfilling well balanced life both personally and professionally. It is a need of time that working women were supposed to care the family both physically and financially in order to satisfy the family needs. Also they had to work for the achivement of corporate goals and personal growth to satisfy the career needs. Organizations were also needed to work on human resource planning and policies in order to overcome the issues of the work life balance of women in the current business environment.

\section{Objectives}

To study the effect of different profession on managing work life balance of working women in India.

\section{Materials and Methods}

The Study: The study is descriptive in nature which described the variations in the professions of Indian women. Study also describes the issues and challenges faced by working women in India. The articles published from 1990 to 2016 were analysed.

The Sample: The relevant data comprised of articles, journals, books and literature available on internet from various research organizations and government establishments. More than 30 articles were reviewed for study.

Tools for Data Collection: Primary data has been collected by using self administered scale which was having 40 items. The reliability and validity has been also tested of the scale. Secondary data were also collected from the various sources like various journals, magazines, relevant websites of various companies, etc. 
The Questionnaire is divided into two parts. For the study, out of 800 questionnaire, finally 702 were duly filled. The data of the survey against each question in questionnaire is analyzed. This was done via correlation with the review of literature and statistical inferences.

\section{Tools for Data Analysis}

The Questionnaire was duly tested for its reliability and validity, the researcher has applied Reliability Test (Cronbach Alpha).

The Data was found reliable and valid.

Factor Analysis was performed on 40 questions by Data Reduction technique.

$t$ - test to identify the effect of type of profession on work life balance of working women in India was performed using Independent sample t- Test.

\section{Findings and Analysis}

Effect of type of profession on various factors of work life balance of working women in India.

1. Effect of Type of Profession on overall Work Life Balance

$\mathbf{H}_{\mathbf{0}}$ 1: There is no significant difference between the mean scores of business class working women and service class working women with respect to managing their work life balance.

\section{Result}

Table No. 2 showed ' $t$ ' value 7.919 at degree of freedom ' $2 / 700$ ' is significant at $1 \%$ level. Thus, from results it is found that hypothesis is rejected. This can be inferred that with $99 \%$ confidence level that there is a significant difference between the business class and service class working women with respect to managing their work life balance. From Table 1, it is found that business class women have mean score of 144.184 and service class women have mean score of 136.277 with respect to overall work life balance. This implies that business class women have with a better work life balance than service class women. To a great extent business class women have more control over their lives. Being own boss, have power to take decisions based on ones' choice and comfort. Though business class women also have to work on commitment of clients. But still much of the control of flexibility of doing work is in the hands of business owner. Desai (2011) found that women in full time jobs requires lot of energy and time in comparison to working women who own their work and do it from home. Working women from home were found to be least stressed, better adjusted. But in terms of monetary benefits, Loscocco et al., (1991) found that majority of working women thought of starting small business. Later found that these women business owners, produce lower sales volumes and derive less income in comparison to others.

Table 1: Descriptive Statistics - Based on Profession

\begin{tabular}{|c|c|c|c|c|c|}
\hline \multicolumn{6}{|c|}{ Group Statistics } \\
\hline & Profession & $\mathbf{N}$ & Mean & Std. Deviation & Std. Error Mean \\
\hline \multirow[t]{2}{*}{ Total of all Factors } & Business & 327 & $1.4640 \mathrm{E} 2$ & 13.83118 & .76487 \\
\hline & Service & 375 & $1.3868 \mathrm{E} 2$ & 12.00089 & .61972 \\
\hline \multirow[t]{2}{*}{ Situational Factor 1} & Business & 327 & 22.7645 & 3.42262 & .18927 \\
\hline & Service & 375 & 22.8080 & 4.16446 & .21505 \\
\hline \multirow{2}{*}{$\begin{array}{l}\text { Professional } \\
\text { Environment Factor } 2\end{array}$} & Business & 327 & 19.2416 & 3.69460 & .20431 \\
\hline & Service & 375 & 17.9893 & 3.67094 & .18957 \\
\hline \multirow[t]{2}{*}{ Work Pressure Factor 3} & Business & 327 & 20.9388 & 5.69920 & .31517 \\
\hline & Service & 375 & 18.2960 & 3.91970 & .20241 \\
\hline \multirow{2}{*}{$\begin{array}{l}\text { Women Support System } \\
\text { Factor } 4\end{array}$} & Business & 327 & 16.2813 & 2.68723 & .14860 \\
\hline & Service & 375 & 16.0107 & 2.81894 & .14557 \\
\hline \multirow{2}{*}{$\begin{array}{l}\text { Overall Health (Mind, } \\
\text { Body, Spirit) Factor } 5\end{array}$} & Business & 327 & 12.8440 & 4.09588 & .22650 \\
\hline & Service & 375 & 13.1360 & 3.10428 & .16030 \\
\hline \multirow[t]{2}{*}{ Social Factor 6} & Business & 327 & 9.2171 & 3.06553 & .16952 \\
\hline & Service & 375 & 9.0507 & 2.52476 & .13038 \\
\hline \multirow{2}{*}{$\begin{array}{l}\text { Personal Happiness } \\
\text { Factor }\end{array}$} & Business & 327 & 11.5810 & 2.16328 & .11963 \\
\hline & Service & 375 & 11.2720 & 1.97190 & .10183 \\
\hline \multirow{2}{*}{$\begin{array}{l}\text { Child Development } \\
\text { Factor } 8\end{array}$} & Business & 327 & 7.5382 & 1.49362 & .08260 \\
\hline & Service & 375 & 6.7600 & 1.36652 & .07057 \\
\hline \multirow[t]{2}{*}{ Women Policies Factor 9} & Business & 327 & 6.4343 & 2.18496 & .12083 \\
\hline & Service & 375 & 6.2480 & 2.06702 & .10674 \\
\hline \multirow[t]{2}{*}{ Family Factor 10} & Business & 327 & 18.8410 & 2.78236 & .15386 \\
\hline & Service & 375 & 17.3040 & 3.01127 & .15550 \\
\hline
\end{tabular}


Table 2: Independent Sample $\mathrm{t}$ - Test based on Profession

\begin{tabular}{|c|c|c|c|c|c|c|c|c|c|c|}
\hline \multicolumn{11}{|c|}{ Independent Samples Test } \\
\hline & & \multicolumn{2}{|c|}{$\begin{array}{c}\text { Levene's Test for } \\
\text { Equality of } \\
\text { Variances } \\
\end{array}$} & \multicolumn{7}{|c|}{ t-test for Equality of Means } \\
\hline & & \multirow[t]{2}{*}{$\mathbf{F}$} & \multirow[t]{2}{*}{ Sig. } & \multirow[t]{2}{*}{$t$} & \multirow[t]{2}{*}{ df } & \multirow[t]{2}{*}{$\begin{array}{l}\text { Sig. (2- } \\
\text { tailed) }\end{array}$} & \multirow[t]{2}{*}{$\begin{array}{c}\text { Mean } \\
\text { Difference }\end{array}$} & \multirow[t]{2}{*}{$\begin{array}{l}\text { Std. Error } \\
\text { Difference }\end{array}$} & \multicolumn{2}{|c|}{$\begin{array}{l}\text { 95\% Confidence } \\
\text { Interval of the } \\
\text { Difference }\end{array}$} \\
\hline & & & & & & & & & Lower & Upper \\
\hline \multirow[t]{2}{*}{$\begin{array}{l}\text { Total of all } \\
\text { Factors }\end{array}$} & $\begin{array}{l}\text { Equal variances } \\
\text { assumed }\end{array}$ & 2.936 & .087 & 7.919 & 700 & .000 & 7.72022 & .97496 & 5.80603 & 9.63441 \\
\hline & $\begin{array}{l}\text { Equal variances } \\
\text { not assumed }\end{array}$ & & & 7.842 & 650.251 & .000 & 7.72022 & .98442 & 5.78720 & 9.65324 \\
\hline \multirow[t]{2}{*}{$\begin{array}{l}\text { Situational } \\
\text { Factor } 1\end{array}$} & $\begin{array}{l}\text { Equal variances } \\
\text { assumed }\end{array}$ & 7.550 & .006 & -.150 & 700 & .881 & -.04347 & .29031 & -.61345 & .52650 \\
\hline & $\begin{array}{l}\text { Equal variances } \\
\text { not assumed }\end{array}$ & & & -.152 & 697.607 & .879 & -.04347 & .28648 & -.60594 & .51899 \\
\hline \multirow{2}{*}{$\begin{array}{l}\text { Professional } \\
\text { Environment } \\
\text { Factor } 2\end{array}$} & $\begin{array}{l}\text { Equal variances } \\
\text { assumed }\end{array}$ & .021 & .884 & 4.495 & 700 & .000 & 1.25226 & .27859 & .70529 & 1.79922 \\
\hline & $\begin{array}{l}\text { Equal variances } \\
\text { not assumed }\end{array}$ & & & 4.493 & 685.842 & .000 & 1.25226 & .27871 & .70503 & 1.79948 \\
\hline \multirow{2}{*}{$\begin{array}{l}\text { Work } \\
\text { Pressure } \\
\text { Factor } 3\end{array}$} & $\begin{array}{l}\text { Equal variances } \\
\text { assumed }\end{array}$ & 77.227 & .000 & 7.231 & 700 & .000 & 2.64284 & .36550 & 1.92523 & 3.36045 \\
\hline & $\begin{array}{l}\text { Equal variances } \\
\text { not assumed }\end{array}$ & & & 7.056 & 566.399 & .000 & 2.64284 & .37457 & 1.90713 & 3.37855 \\
\hline \multirow{2}{*}{$\begin{array}{l}\text { Women } \\
\text { Support } \\
\text { System } \\
\text { Factor } 4\end{array}$} & $\begin{array}{l}\text { Equal variances } \\
\text { assumed }\end{array}$ & .243 & .622 & 1.297 & 700 & .195 & .27068 & .20871 & -.13908 & .68044 \\
\hline & $\begin{array}{l}\text { Equal variances } \\
\text { not assumed }\end{array}$ & & & 1.301 & 694.448 & .194 & .27068 & .20802 & -.13775 & .67911 \\
\hline \multirow{2}{*}{$\begin{array}{l}\text { Overall } \\
\text { Health (Mind, } \\
\text { Body, Spirit) } \\
\text { Factor } 5\end{array}$} & $\begin{array}{l}\text { Equal variances } \\
\text { assumed }\end{array}$ & 83.634 & .000 & -1.072 & 700 & .284 & -29196 & .27240 & -.82678 & .24286 \\
\hline & $\begin{array}{l}\text { Equal variances } \\
\text { not assumed }\end{array}$ & & & -1.052 & 602.590 & .293 & -.29196 & .27749 & -.83693 & .25300 \\
\hline \multirow[t]{2}{*}{$\begin{array}{l}\text { Social Factor } \\
6\end{array}$} & $\begin{array}{l}\text { Equal variances } \\
\text { assumed }\end{array}$ & 36.283 & .000 & .789 & 700 & .431 & .16646 & .21107 & -.24795 & .58087 \\
\hline & $\begin{array}{l}\text { Equal variances } \\
\text { not assumed }\end{array}$ & & & .778 & 632.744 & .437 & .16646 & .21386 & -.25351 & .58642 \\
\hline
\end{tabular}




\begin{tabular}{|l|l|c|c|c|c|c|c|c|c|c|}
\hline $\begin{array}{l}\text { Personal } \\
\text { Happiness } \\
\text { Factor }\end{array}$ & $\begin{array}{l}\text { Equal variances } \\
\text { assumed }\end{array}$ & .253 & .615 & 1.980 & 700 & .048 & .30904 & .15611 & .00254 & .61554 \\
\cline { 2 - 10 } & $\begin{array}{l}\text { Equal variances } \\
\text { not assumed }\end{array}$ & & & 1.967 & 665.167 & .050 & .30904 & .15710 & .00057 & .61751 \\
\hline $\begin{array}{l}\text { Child } \\
\text { Development } \\
\text { Factor 8 }\end{array}$ & $\begin{array}{l}\text { Equal variances } \\
\text { assumed }\end{array}$ & .001 & .979 & 7.207 & 700 & .000 & .77823 & .10798 & .56622 & .99023 \\
\cline { 2 - 10 } \\
$\begin{array}{l}\text { Equal variances } \\
\text { not assumed }\end{array}$ & & & 7.164 & 666.204 & .000 & .77823 & .10864 & .56491 & .99154 \\
\hline $\begin{array}{l}\text { Women } \\
\text { Policies } \\
\text { Factor 9 }\end{array}$ & $\begin{array}{l}\text { Equal variances } \\
\text { assumed }\end{array}$ & 1.533 & .216 & 1.160 & 700 & .247 & .18625 & .16061 & -.12909 & .50159 \\
\cline { 2 - 10 } & $\begin{array}{l}\text { Equal variances } \\
\text { not assumed }\end{array}$ & & & 1.155 & 675.021 & .248 & .18625 & .16122 & -.13031 & .50281 \\
\hline $\begin{array}{l}\text { Family Factor } \\
10\end{array}$ & $\begin{array}{l}\text { Equal variances } \\
\text { assumed }\end{array}$ & 3.741 & .053 & 6.988 & 700 & .000 & 1.53698 & .21994 & 1.10515 & 1.96881 \\
\cline { 2 - 10 } & $\begin{array}{l}\text { Equal variances } \\
\text { not assumed }\end{array}$ & & & 7.026 & 697.643 & .000 & 1.53698 & .21876 & 1.10748 & 1.96648 \\
\hline
\end{tabular}




\section{Effect of Type of Profession on Situational Factors}

H02: There is no significant difference between the mean scores of business class working women and service class working women with respect to situational factors.

\section{Result}

Table No. 2 shows, 't' value ' -0.150 '. Thus, from results it is found that hypothesis is not rejected, implies that null hypothesis $\mathrm{H}_{0} 2$ is not rejected. This can be inferred that there is no significant difference between the business class and service class working women with respect to Situational Factors. From Table 1, it is found that business class women shows mean value 22.7645, whereas service class women shows mean value 22.8080 . This implies that service class women has slightly better work life balance than business class women.

\section{Effect of Type of Profession on Professional Environmental Factors}

H03: There is no significant difference between the mean scores of business class working women and service class working women with respect to professional environmental factors.

\section{Result}

Table No. 2 shows, ' $t$ ' value 4.495 at degree of freedom ' $2 / 700$ 'is significant at $1 \%$ level. Thus, from results it is found that hypothesis is rejected. This can be inferred that with $99 \%$ confidence level that there is a significant difference between the business class working women and service class working women with respect to Professional Environmental Factors. From Table 1, it is found that of business class women shows mean value 19.2416, whereas service class women shows mean value 17.9893. This implies that business class women has much better work life balance than service class women. Shiva (2013) found that Women working in public sector having more organization satisfaction than private sector. The leading cause of stress arises because of communication with superior. Ahemad (2013) found women in jobs have more job anxieties than other women. They find difficulty in balancing personal and work life. For better growth, organization must give better professional environment.

\section{Effect of Type of Profession on Work Pressure Factors}

H04: There is no significant difference between the mean scores of business class working women and service class working women with respect to work pressure factors.

\section{Result}

Table No. 2 shows, ' $t$ ' value 7.231 at degree of freedom ' $2 / 700$ ' is significant at $1 \%$ level. Thus, from results it is found that hypothesis is rejected. This can be inferred that with $99 \%$ confidence level that there is a significant difference between the business class working women and service class working women with respect to Work Pressure Factors. From Table 1, it is found that business class women shows mean value 20.9388, whereas service class women shows mean value 18.296. This implies that business class women has much better work life balance than service class women.

\section{Effect of Type of Profession on Women Support System Factors}

Ho5: There is no significant difference between the mean scores of business class working women and service class working women with respect to women support system factors.

Result

Table No. 2 shows, 't' value 1.297. Thus, from results it is found that hypothesis is not rejected, implies that null hypothesis $\mathrm{H}_{0} 5$ is not rejected. This can be inferred that there is not a significant difference between the business class and service class working women with respect to Women Support System Factors. From Table 1, under Women Support System Factors of work life balance, it is found that business class women shows mean value 16.2813 , whereas service class women shows mean value 16.0107. This implies that business class women has slightly better work life balance than service class women.

\section{Effect of Type of Profession on Overall Health (Body, Mind and Spirit) Factors}

Ho6: There is no significant difference between the mean scores of business class working women and service class working women with respect to overall health (body, mind and spirit) factors.

\section{Result}

Table No. 2 shows, ' $t$ ' value ' -1.072 '. Thus, from results it is found that hypothesis is not rejected, implies that null hypothesis $\mathrm{H}_{0} 6$ is not rejected. This can be inferred that there is not a significant difference between the business class working women and service class working women with respect to Overall Health (Body, Mind and Spirit) Factors. From Table 1, it is found that business class women shows mean value 12.844, whereas service class women shows mean value 13.136. This implies that business class women has far much better work life balance than service class women. Business class women has more control over their mind, body and spirit factors i.e. business class women enjoys better health than service class women.

\section{Effect of Type of Profession on Social Factors}

Ho7: There is no significant difference between the mean scores of business class working women and 
service class working women with respect to social factors.

\section{Result}

Table No. 2 shows, ' $t$ ' value 0.789 . Thus, from results it is found that hypothesis is not rejected, implies that null hypothesis $\mathrm{H}_{0} 7$ is not rejected. This can be inferred that here is not a significant difference between the business class working women and service class working women. From Table 1, under Social Factors of work life balance, it is found that business class women shows mean value 9.2171, whereas service class women shows mean value 9.057 . This implies that business class women has much better work life balance than service class women.

\section{Effect of Type of Profession on Personal Happiness Factors}

Ho8: There is no significant difference between the mean scores of business class working women and service class working women with respect to personal happiness factors.

\section{Result}

Table No. 2 shows, ' $t$ ' value 1.980 at degree of freedom ' $2 / 700$ ' is significant at $5 \%$ level. Thus, from results it is found that hypothesis is rejected. This can be inferred that with $95 \%$ confidence level that there is a significant difference between the business class and service class working women. From Table 1 , under Personal Happiness Factors of work life balance, it is found that business class women shows mean value 11.581, whereas service class women shows mean value 11.2720. This implies business class women has much better work life balance than service class women. Florida (2012) found that the emergence of a new social class, the Creative Class. This new class changed the way we lived and worked. Human creativity is the most marvelously transforming the economic front too. The augmentation reality of the creativity class though faces challenges, but their determination will bear fruits of happier life. Rather than working for hard core technologies, this new genre would be more connected to themselves. This class could be able to find time for oneself and family along with work, and live more effectively with personal happiness in life. Since 1960s, happiness research has been conducted in a wide variety of scientific disciplines, like social psychology, gerontology, clinical and medical research and happiness economics. The $20^{\text {th }}$ March is declared as the International Day of Happiness by The United Nations to recognize the relevance of happiness and well-being as universal goals.

In 1960, Jung was interviewed by journalist Gordon Young, for basic factors making for happiness:

1. Good physical and mental health.
2. Good personal and intimate relationships, such as those of marriage, the family, and friendships.

3. The faculty for perceiving beauty in art and nature.

4. Reasonable standards of living and satisfactory work.

A philosophic or religious point of view capable of coping successfully with the vicissitudes of life.

\section{Effect of Type of Profession on Child Development Factors}

Ho9: There is no significant difference between the mean scores of business class working women and service class working women with respect to child development factors.

\section{Result}

Table No. 2 shows, 't' value 7.207 at degree of freedom ' $2 / 700$ 'is significant at $1 \%$ level. Thus, from results it is found that hypothesis is rejected. This can be inferred that with $99 \%$ confidence level that there is a significant difference between the business class and service class working women with respect to Child Development Factors. From Table 1, it is found that business class women shows mean value 7.5382, whereas service class women shows mean value 6.76 . This implies that business class women has much better work life balance than service class women. White (2003) found surprisingly, the presence of young children has become less important over time. Overall, the results suggest a conflict between high-performance practices and work-life balance policies.

\section{Effect of Type of Profession on Women Policies Factors}

Ho10: There is no significant difference between the mean scores of business class working women and service class working women with respect to women policies factors.

\section{Result}

Table No. 2 shows, ' $t$ ' value 1.160. Thus, from results it is found that hypothesis is not rejected, implies that null hypothesis $\mathrm{H}_{0} 10$ is not rejected.. This can be inferred that there is not a significant difference between the business class working women and service class working women with respect to Women Policies Factors. From Table 1, it is found that business class women shows mean value 6.4343 , whereas service class women shows mean value 6.2480. This implies that business class women has much better work life balance than service class women.

\section{Effect of Type of Profession on Family Factors}

Ho11: There is no significant difference between the mean scores of business class working women and service class working women with respect to family factors. 


\section{Result}

Table No. 2 shows, ' $t$ ' value 6.988 at degree of freedom ' $2 / 700$ 'is significant at $1 \%$ level. Thus, from results it is found that hypothesis is rejected. This can be inferred that with $99 \%$ confidence level that there is a significant difference between the business class working women and service class working women with respect to Family Factors. From Table 1, it is found that business class women shows mean value 18.841, whereas service class women shows mean value 17.304. This implies that business class women has much better work life balance than service class. Buddhapriya (2009) found that 'lack of gender sensitive policies by the business owners' and 'commitment to family responsibility' were major obstacles hampering career growth of women professionals to senior positions. Valk and Srinivasan (2011) found that Indian working women become inclined to perform the roles of dependent care provider and home maker. Women being the key hold of family responsibilities and best manager of human relations, she chooses her family life over career. Women's sacrifice their career as a conscious choice for the family needs. If family needs its member, and that person becomes available for them in real need, normally it is found they will support her in her tough times too.

\section{Conclusion}

It is important to note that the varying perspectives for women respect, education, empowerment, involvements in all fields, burgeoning women entrepreneurship were independent of the age. Yet the dignified ethical Indian women imbibed with her the vibes of deep rooted cultural foundation and strong core values as part of inherent personality glorified internationally across the globe the saga of Great Indian civilization

The understanding and the notions of women role in ancient and medieval period was quite different from those of the present world. Modern India is working on shaping back Women's image as educated, intelligentsia, high profile, professionals, corporate, business elegance, in global perspective. Un-doubtable acceptance on women are better managers than male counterparts are growing. The structure of today's society is based on the spirit of democracy and justice. Any kind of discrimination on any ground, including the sexual one, is considered as injustice. The fundamental objectives of Indian system is to work on world peace and let humanity prevail its values with happy living for all.

It can also be concluded that there is a need of more in-depth studies for Indian working women work life balance problem. This study is just a tip of the iceberg. The issue is a deeper one related to work life balance of working women in India. The few studies that have touched on this issue are also done basically in the western context. Their applicability in the Indian context and specially for women needs to be further explored.

\section{References}

1. Ahemad, M. M. (2013). A Review of Quality of Work Life Balance for Women Employees, www.semanticscholar.org

2. Baral, R. A. (2010). Work-Family Enrichment as a Mediator between Organizational Interventions for WorkLife Balance and Job Outcomes. Journal of Managerial Psychology, 25 (3),274-300.

3. Buddhapriya, S. (2009). Work Family Challenges and Their Impact on Career Decisions: A Study of Indian Women Professionals. Vikalpa, 34 (1),31-46.

4. Butler, A., Grzywacz, J., Bass, B., and Linney, K. (2005). Extending the demands-control model: A daily diary study of job characteristics, work-family conflict and work-family facilitation. Journal of occupational and organizational psychology, 78(2), 155-69.

5. Dileepkumar. (2006). Problems of Women Entrepreneurs in India. Symbiosis (SCMHRD, SCDL), IIIT, SCMLD, SBS Pune.

6. Frone, M. R., Russell, M., and Cooper, M. L. (1992). Antecedents and outcomes of work-family conflict: testing a model of the work-family interface. Journal of applied psychology, 77(1), 65.

7. Hyman, Jeff and Summers, Juliette (2004). Lacking balance? Work-life employment practices in the modern economy. Personnel Review, 33(4), 418-429.

8. Jaafari, A. (2003). Project management in the age of complexity and change. Project Management Journal , 34 (4), 47-58.

9. Lockwood, N. (2003). Workorlife balance: Challenges and solutions. Society for Human Resource Management

10. Mathew, R. V. (2011). An Exploratory Study on the Work-Life Balance of Women Entrepreneurs in South India. Asian academy of management journal, 16 (2),77105 .

11. Muthumani, K. G. (2013). Creating Constructive Work Environment to Improve Quality of Work Life of Coimbatore Based IT Professionals. ZENITH International Journal of Multidisciplinary Research, 3 (2), 98-107.

12. Perrons, D. (2003). The new economy and the work-life balance: Conceptual explorations and a case study of new media. Gender, Work and Organization, 10 (1),65-93.

13. Shravanthi, Andukuri. Raj, Deshmukh, Sagar, and Deepa, N. (2013). Work Life Balance of Women in India. International Journal of Research in Management Sciences, 1(1), 50.

14. Sudha, J. and Karthikeyan, P. (2014). Work life balance of women employee: A literature review. International Journal of Management Research and Reviews, 4(8), 797.

15. White, M. H. (2003). High performance management practices, working hours and work-life balance. . British Journal of Industrial Relations , 41 (2), 175-95. 